\title{
Proceeding
}

Supplementary Issue: Autumn Conferences of Sports Science. Costa Blanca Sports Science Events, 18-19 December 2020. Alicante, Spain.

\section{Embodied cognition, effective learning and physical activity as a shared feature: Systematic review}

\author{
MANUELA VALENTINI ${ }^{1}$, SIMONE GUARNACCI ${ }^{2}$ \\ ${ }^{1}$ Department of Humanities, University of Urbino Carlo Bo, Urbino, Italy \\ 2Primary School Educator, Italy
}

\begin{abstract}
Background: according to the embodied cognition perspective, the interaction of the body with the environment builds knowledge, and physical activity can enhance cognitive development. Methodology: the purpose of this research is to conduct a systematic literature review of studies on the integration between physical activity and mathematics in the context of primary school and the effects on learning resulting from these types of intervention. Findings: bibliographic research led to the selection of 34 studies. Analysis of the protocols revealed that motor activity could have a positive impact on learning mathematics and in no case affects it negatively. Conclusions: this method of teaching can also contribute to improved pupils' participation in educational activities, increased motivation, greater well-being, and reduced sedentary lifestyle. Further research could assess the extensibility of these studies to contexts beyond primary school and their impact on teaching.
\end{abstract}

Keywords: Maths teaching; Physical activity; Physical education; Primary school; Subject integration.

\section{Cite this article as:}

Valentini, M., \& Guarnacci, S. (2021). Embodied cognition, effective learning and physical activity as a shared feature: Systematic review. Journal of Human Sport and Exercise, 16(2proc), S539-S552. doi:https://doi.org/10.14198/jhse.2021.16.Proc2.38

Corresponding author. Department of Humanities, University of Urbino Carlo Bo, Urbino, Italy.

E-mail: manuela.valentini@uniurb.it

Abstract submitted to: Autumn Conferences of Sports Science. Costa Blanca Sports Science Events, 18-19 December 2020. Alicante, Spain.

JOURNAL OF HUMAN SPORT \& EXERCISE ISSN 1988-5202

(c) Faculty of Education. University of Alicante

doi:10.14198/jhse.2021.16.Proc2.38 


\section{INTRODUCTION}

For some years we have witnessed the recovery and appreciation of the bodily dimension in the construction of knowledge; research in this area resulted in the development of the embodied cognition construct according to which the mind is as if it were "grounded in the details of its sensory-motor embodiment" (Foglia \& Wilson, 2013, p. 319). Within this field of research, there are also significant contributions by Barsalou $(1999,2008,2010)$ who opted for the term grounded rather than embodied, considering the former to be more comprehensive.

Research on mirror neurons (Rizzolatti \& Craighero, 2004) also demonstrated how tangible actions such as observation, simulation of other people's gestures and imitation are central to learning. Advances in technology have enabled ever more in-depth research in the neurological field to understand the correlation between the activities carried out and brain areas involved (Meister et al., 2003).

In addition to the consideration of the aspects related to the bodily dimension of learning, it is important to structure a way of teaching that allows the optimization of cognitive resources and in this regard, the contributions of the Cognitive Load Theory (Sweller, 1988) are important and have affected problem-solving modalities. It has also been considered the management of elements, during learning processes that happen in the working memory, and this can be compared to the mere storage that instead occurs in short-term memory (Baddeley, 2012).

The topic of didactics leads us to focus on knowledge built in formal contexts of learning such as school. This type of knowledge is considered by Geary $(1995,2008)$ as biologically secondary and to be acquired it requires precise intentionality besides a different effort and more time than the primary knowledge; we need the latter to satisfy the essential survival needs.

Therefore, it seems possible to exploit the potential inherent in the school context as a privileged area to promote meaningful learning and allow for the harmonious growth of children. Within the framework of the Cognitive Load Theory, instructional design (Sweller, 2006) is configured as a careful design method that permits adequate cognitive engagement in the learners for whom the learning processes may then take place in the best conditions.

If we consider the person in all his dimensions, we cannot neglect emotions that are important to be taken care of in any educational relationship; learning happens through the body and this tangible entity expresses emotions that give depth to the learning processes. The importance of the emotional dimension was stressed by Moreno (2010) who integrated the Cognitive Load Theory considering the affective dimension and, in our opinion, it is also important for the teacher to create an emotional scaffolding (Meyer \& Turner, 2007).

Another aspect of human cognition, functional to the understanding of its actual mechanisms and enabling teachers to intervene in an increasingly targeted way from an educational point of view, emerged from studies on executive functions (Miyake et al., 2000; Diamond, 2013), integrated processes that regulate cognitive activities. These functions play a significant role in learning (Blair \& Razza, 2007; Morrison et al., 2010; Gathercole et al., 2004) as the individual's cognitive resources are fully mobilized to learn.

Promoting the development of executive functions can therefore positively affect learning and these functions can be stimulated considering both the emotional dimension (Raver \& Blair, 2016) and through physical activity (De Greeff et al., 2018); from the latter, a neuronal development occurs in the brain areas responsible 
for memory and learning (Cotman et al., 2007). This can be linked to the relationship between physical health and growth of the brain structures where activities related to movement and executive functions are managed (Chaddock et al., 2010). Furthermore, the development of executive functions has a predictive value for skills in mathematics and other disciplines (Espy et al., 2004; Gashaj et al., 2018).

If physical activity and the body are directly involved in the development and execution of the cognitive processes through which learning takes place, the school can be regarded as a privileged context in which to foster an early stimulation of these processes. Assessing the positive impact of physical activity on the cognitive dimension, we have taken into consideration the possibility of achieving a disciplinary integration between physical activity and mathematics, and we began looking for research that was carried out with primary school pupils as it is at this point when there is a clearer distinction (compared to nursery school) between disciplinary areas and educational intervention can be conducted in a more targeted way. From the analysis of the selected studies, we wanted to understand what data could emerge on the effects of disciplinary integration and the impact of this on the subjects involved and on other disciplines. Subsequently, we tried to evaluate the possible extensibility of these practices to contexts other than those examined and the impact of these teaching methods on didactics.

\section{METHOD}

We started our research by analysing the PsycINFO, PsycARTICLES, SPORTDiscus, WOS (Web of Science), ERIC, and Jstor databases. We followed the PRISMA guidelines (Moher et al., 2009). Starting from the above-mentioned databases and through keywords and their combination using Boolean connectives (and, or, not) we looked for publications in Italian and English between 2000 and 2020. We then proceeded to a manual search including the Google Scholar and BASE databases to find keywords in the titles, abstracts, and descriptors. Then we proceeded to delve into the topics also by searching with the usage of synonyms of the initial keywords. We conducted a systematic manual search in the bibliographies and references found in the analysed publications.

We also considered articles reviewed by experts and from academic sources or which we found traceable and reliable; we looked for studies developed in different contexts and not limited to a restricted geographical area or socio-economic conditions. We also searched for any follow-up on the analysed protocols. The research did not include studies involving children with clinical conditions or ascertained difficulties in the motor competencies, and we focused on children aged between 5 and 11, a range indicative of primary school attendance. Finally, we proceeded to create e-mail alerts for any new article to be included in the search and organized the results of the research also using bibliographic management software (Zotero and Mendeley).

From the identification of 2394 initial articles, through analysis and subsequent screening, we eventually included 34 studies in the systematic review.

These were analysed and the information obtained was organized and summarised in a table (Table 1) considering the year and country in which the research was conducted, the disciplines involved, the learning context, the aims of the research, the effects (primary and, if present, secondary ones) resulting from the application of the protocols. 
Table 1. Summary table of the studies included in the systematic review.

\begin{tabular}{|c|c|c|c|c|c|c|}
\hline Author & Subj & Age & Activity & Duration & Results & Journal \\
\hline $\begin{array}{l}\text { Donnelly et al. } \\
2009 \text { USA }\end{array}$ & 203 & $7-8$ & $\begin{array}{l}\text { Curriculum } \\
\text { integrated } \\
\text { Physical } \\
\text { Activity (PAAC) }\end{array}$ & 3 years & $\begin{array}{l}\text { Improvements in } \\
\text { mathematics, } \\
\text { spelling, and } \\
\text { reading }\end{array}$ & $\begin{array}{l}\text { Preventive } \\
\text { Medicine }\end{array}$ \\
\hline $\begin{array}{l}\text { Davis et al. } \\
2011 \text { USA }\end{array}$ & 171 & 9 & $\begin{array}{l}\text { After school } \\
\text { PA }\end{array}$ & 3 months & $\begin{array}{l}\text { Development of } \\
\text { executive } \\
\text { functions and } \\
\text { mathematics } \\
\text { performance }\end{array}$ & $\begin{array}{l}\text { Health } \\
\text { psychology (APA) }\end{array}$ \\
\hline $\begin{array}{l}\text { Erwin et al. } \\
2012 \text { USA }\end{array}$ & 29 & 8 & $\begin{array}{l}\text { PA and maths } \\
\text { learning }\end{array}$ & 20 weeks & $\begin{array}{l}\text { Improved results } \\
\text { in maths and } \\
\text { reading }\end{array}$ & $\begin{array}{l}\text { International } \\
\text { Electronic Journal } \\
\text { of Elementary } \\
\text { Education }\end{array}$ \\
\hline $\begin{array}{l}\text { Lopes et al. } \\
2013 \text { Portugal }\end{array}$ & 596 & $9-12$ & $\begin{array}{l}\text { Motor } \\
\text { coordination } \\
\text { and academic } \\
\text { results }\end{array}$ & $\begin{array}{l}\text { School year } \\
2009-2010\end{array}$ & $\begin{array}{l}\text { Motor coordination } \\
\text { difficulties linked } \\
\text { to worse results in } \\
\text { maths and } \\
\text { Portuguese }\end{array}$ & $\begin{array}{l}\text { Human } \\
\text { Movement } \\
\text { Science }\end{array}$ \\
\hline $\begin{array}{l}\text { Hu et al. } 2014 \\
\text { Australia }\end{array}$ & 114 & $9-11$ & $\begin{array}{l}\text { Solving } \\
\text { geometry } \\
\text { problems using } \\
\text { fingers }\end{array}$ & $\begin{array}{l}\text { 30-minute } \\
\text { individual test }\end{array}$ & $\begin{array}{l}\text { Improved learning } \\
\text { of mathematical } \\
\text { concepts }\end{array}$ & $\begin{array}{l}\text { Learning and } \\
\text { Instruction }\end{array}$ \\
\hline $\begin{array}{l}\text { Smith et al. } \\
2014 \text { USA }\end{array}$ & 20 & $8-9$ & $\begin{array}{l}\text { Angles } \\
\text { explained } \\
\text { through bodily } \\
\text { experiences } \\
\text { (Windows } \\
\text { Kinect) } \\
\end{array}$ & $\begin{array}{l}15-20 \\
\text { minutes of } \\
\text { activity plus } \\
\text { an individual } \\
\text { interview }\end{array}$ & $\begin{array}{l}\text { Improved } \\
\text { classification, } \\
\text { estimation, and } \\
\text { representation of } \\
\text { angles. }\end{array}$ & $\begin{array}{l}\text { The Journal of } \\
\text { Mathematical } \\
\text { Behavior }\end{array}$ \\
\hline $\begin{array}{l}\text { Vazou \& } \\
\text { Smiley-Oyen } \\
2014 \text { USA }\end{array}$ & 35 & $9-11$ & $\begin{array}{l}\text { Lessons with } \\
10 \text { minutes of } \\
\text { PA or without } \\
\text { movement }\end{array}$ & $\begin{array}{l}2 \text { days: one } \\
\text { with PA and } \\
\text { the other } \\
\text { without it }\end{array}$ & $\begin{array}{l}\text { PA combined with } \\
\text { maths fosters the } \\
\text { development of } \\
\text { executive functions }\end{array}$ & $\begin{array}{l}\text { Journal of Sport } \\
\text { \& Exercise } \\
\text { Psychology }\end{array}$ \\
\hline $\begin{array}{l}\text { Agostinho et } \\
\text { al. } 2015 \\
\text { Australia }\end{array}$ & 61 & $8-11$ & $\begin{array}{l}\text { Primary } \\
\text { knowledge } \\
\text { supports the } \\
\text { secondary } \\
\text { one } \\
\end{array}$ & $\begin{array}{l}\text { Individual } \\
\text { activities, } 25 \\
\text { minutes per } \\
\text { participant on } \\
\text { average }\end{array}$ & $\begin{array}{l}\text { Graphs drawing with } \\
\text { fingers helps children } \\
\text { understand graphical } \\
\text { representations }\end{array}$ & $\begin{array}{l}\text { Educational } \\
\text { Psychology } \\
\text { Review }\end{array}$ \\
\hline $\begin{array}{l}\text { Fedewa et al. } \\
2015 \text { USA }\end{array}$ & 460 & $8-10$ & $\begin{array}{l}\text { 5-minute } \\
\text { breaks with } \\
\text { PA; } 20 \\
\text { mins/day }\end{array}$ & 8 months & $\begin{array}{l}\text { Breaks involving PA } \\
\text { led to better results in } \\
\text { maths and reading. }\end{array}$ & $\begin{array}{l}\text { School } \\
\text { Psychology } \\
\text { International }\end{array}$ \\
\hline $\begin{array}{l}\text { Howie et al. } \\
2015 \text { USA }\end{array}$ & 96 & $9-11$ & $\begin{array}{l}\text { Active breaks } \\
\text { VS sitting } \\
\text { lessons }\end{array}$ & 3 months & $\begin{array}{l}10 \text { and } 20 \text {-minute } \\
\text { breaks involving PA } \\
\text { improve results in } \\
\text { maths }\end{array}$ & $\begin{array}{l}\text { Research } \\
\text { Quarterly for } \\
\text { Exercise and } \\
\text { Sport } \\
\end{array}$ \\
\hline $\begin{array}{l}\text { Mullender } \\
\text { Wijnsma et al. } \\
2015 \\
\end{array}$ & 228 & 8 & $\begin{array}{l}\text { MVPA } \\
\text { (moderate to } \\
\text { vigorous PA) } \\
\end{array}$ & $\begin{array}{l}21 \text { weeks, } 3 \\
\text { lessons per } \\
\text { week }\end{array}$ & $\begin{array}{l}\text { 3rd year pupils } \\
\text { performed better at } \\
\text { maths and reading }\end{array}$ & $\begin{array}{l}\text { Journal of } \\
\text { School Health }\end{array}$ \\
\hline
\end{tabular}




\begin{tabular}{|c|c|c|c|c|c|c|}
\hline Netherlands & & & $\begin{array}{l}\text { in maths and } \\
\text { reading } \\
\text { lessons }\end{array}$ & & $\begin{array}{l}\text { compared to those in } \\
\text { the } 2 \text { nd year }\end{array}$ & \\
\hline $\begin{array}{l}\text { Riley et al. } \\
2015 \text { Australia }\end{array}$ & 58 & $9-11$ & $\begin{array}{l}\text { EASY minds } \\
\text { program }\end{array}$ & 6 weeks & $\begin{array}{l}\text { Improves } \\
\text { concentration, } \\
\text { increases maths } \\
\text { learning and lesson } \\
\text { liking }\end{array}$ & $\begin{array}{l}\text { Journal of } \\
\text { Science and } \\
\text { Medicine in } \\
\text { Sport }\end{array}$ \\
\hline $\begin{array}{l}\text { Ruiter et al. } \\
2015 \\
\text { Netherlands } \\
\text { and Australia }\end{array}$ & 118 & 6 & $\begin{array}{l}\text { Two-digit } \\
\text { numbers } \\
\text { through } \\
\text { activities with } \\
\text { or without } \\
\text { motor stimuli }\end{array}$ & $\begin{array}{l}\text { Various } \\
\text { school days: } \\
\text { physical } \\
\text { activities and } \\
\text { individual } \\
\text { tests }\end{array}$ & $\begin{array}{l}\text { Embodied practices } \\
\text { contribute to a better } \\
\text { understanding of } \\
\text { maths concepts }\end{array}$ & $\begin{array}{l}\text { Educational } \\
\text { Psychology } \\
\text { Review }\end{array}$ \\
\hline $\begin{array}{l}\text { Goh et al. } 2016 \\
\text { USA }\end{array}$ & 210 & $8-10$ & $\begin{array}{l}\text { TAKE10 (PA } \\
\text { with maths and } \\
\text { other subjects) }\end{array}$ & 8 weeks & $\begin{array}{l}\text { Better results in } \\
\text { maths and } \\
\text { reduction of } \\
\text { distraction }\end{array}$ & $\begin{array}{l}\text { Journal of } \\
\text { Physical Activity \& } \\
\text { Health }\end{array}$ \\
\hline $\begin{array}{l}\text { Mullender } \\
\text { Wijnsma et al. } \\
2016 \\
\text { Netherlands }\end{array}$ & 499 & 8 & $\begin{array}{l}\text { PA in maths } \\
\text { and spelling } \\
\text { lessons }\end{array}$ & $\begin{array}{l}2 \text { years; } 22 \\
\text { weeks per } \\
\text { year, } 3 \\
\text { lessons per } \\
\text { week }\end{array}$ & $\begin{array}{l}\text { Improved both } \\
\text { areas }\end{array}$ & Pediatrics \\
\hline $\begin{array}{l}\text { Snyder et al. } \\
2017 \text { USA }\end{array}$ & 34 & 8 & $\begin{array}{l}\text { PA integrated } \\
\text { with maths }\end{array}$ & 5 weeks & $\begin{array}{l}\text { Better motivation } \\
\text { and focus, same } \\
\text { maths results }\end{array}$ & $\begin{array}{l}\text { International } \\
\text { Journal of } \\
\text { Research in } \\
\text { Education and } \\
\text { Science }\end{array}$ \\
\hline $\begin{array}{l}\text { Vazou \& } \\
\text { Skrade } 2017 \\
\text { USA }\end{array}$ & 106 & $9-10$ & $\begin{array}{l}\text { "Move for } \\
\text { thought" (Maths } \\
\text { integrated with } \\
\text { PA) }\end{array}$ & 8 weeks & $\begin{array}{l}\text { Improved maths } \\
\text { results and more } \\
\text { motivation. }\end{array}$ & $\begin{array}{l}\text { International } \\
\text { Journal of Sport } \\
\text { and Exercise } \\
\text { Psychology }\end{array}$ \\
\hline $\begin{array}{l}\text { Elofsson et al. } \\
2018 \text { Sweden }\end{array}$ & 53 & 6 & $\begin{array}{l}\text { Math in Action } \\
\text { (MIA) } \\
\text { Maths } \\
\text { integrated with } \\
\text { PA and music }\end{array}$ & 3 weeks & $\begin{array}{l}\text { Better results and } \\
\text { more participation } \\
\text { of children with } \\
\text { different motor } \\
\text { skills levels }\end{array}$ & Education 3-13 \\
\hline $\begin{array}{l}\text { Gashaj et al. } \\
2018 \\
\text { Switzerland }\end{array}$ & 136 & $6-8$ & $\begin{array}{l}\text { Analysis of the } \\
\text { predictive value } \\
\text { of fine motor } \\
\text { skills and } \\
\text { executive } \\
\text { functions for } \\
\text { maths skills }\end{array}$ & 18 months & $\begin{array}{l}\text { Significant } \\
\text { correlations } \\
\text { among motor, } \\
\text { maths skills, and } \\
\text { executive } \\
\text { functions }\end{array}$ & $\begin{array}{l}\text { Early Education } \\
\text { and Development }\end{array}$ \\
\hline $\begin{array}{l}\text { Griffo et al. } \\
2018 \text { USA }\end{array}$ & 55 & $8-12$ & $\begin{array}{l}\text { KIA } \\
\text { (knowledge in } \\
\text { action) Maths } \\
\text { and PA lessons }\end{array}$ & 2 weeks & $\begin{array}{l}\text { Improved maths, } \\
\text { increased PA, } \\
\text { more participation } \\
\text { in lessons }\end{array}$ & Physical Educator \\
\hline $\begin{array}{l}\text { Have et al. } \\
2018 \\
\text { Denmark }\end{array}$ & 505 & 7 & $\begin{array}{l}\text { PA integrated } \\
\text { with maths } \\
\text { lessons }\end{array}$ & 9 months & $\begin{array}{l}\text { Improved results in } \\
\text { maths; enhanced if } \\
\text { combined with }\end{array}$ & PLOS ONE \\
\hline
\end{tabular}


motor activity

\begin{tabular}{|c|c|c|c|c|c|c|}
\hline $\begin{array}{l}\text { Mavilidi et al. } \\
2018 \text { Australia }\end{array}$ & 120 & 5 & $\begin{array}{l}\text { PA integrated } \\
\text { with maths } \\
\text { cognitive } \\
\text { tasks }\end{array}$ & 4 weeks & $\begin{array}{l}\text { Better results with } \\
\text { PA, compared to } \\
\text { observation only }\end{array}$ & $\begin{array}{l}\text { Journal of } \\
\text { Experimental Child } \\
\text { Psychology }\end{array}$ \\
\hline $\begin{array}{l}\text { Resaland et } \\
\text { al. } 2018 \\
\text { Norway }\end{array}$ & 1129 & 10 & $\begin{array}{l}\text { ASK (Active } \\
\text { Smarter Kids), } \\
\text { PA and active } \\
\text { breaks }\end{array}$ & 7 months & $\begin{array}{l}\text { Most effective for } \\
\text { pupils who had the } \\
\text { lowest marks in } \\
\text { maths }\end{array}$ & Preventive Medicine \\
\hline $\begin{array}{l}\text { Vetter et al. } \\
2018 \text { Australia }\end{array}$ & 85 & $9-10$ & $\begin{array}{l}\text { Learning } \\
\text { times tables } \\
\text { through } \\
\text { integrated PA }\end{array}$ & $\begin{array}{l}6 \text { weeks: } 3 \\
\text { times a } \\
\text { week, } 20 \\
\text { mins each }\end{array}$ & $\begin{array}{l}\text { Positive outcomes } \\
\text { for learning times } \\
\text { tables }\end{array}$ & $\begin{array}{l}\text { Journal of Physical } \\
\text { Activity and Health }\end{array}$ \\
\hline $\begin{array}{l}\text { Asakawa et al. } \\
2019 \text { Japan }\end{array}$ & 80 & 7 & $\begin{array}{l}\text { Effects of fine } \\
\text { motor training } \\
\text { on maths } \\
\text { skills }\end{array}$ & 6 weeks & $\begin{array}{l}\text { Fine motor skills } \\
\text { influence maths } \\
\text { skills. }\end{array}$ & $\begin{array}{l}\text { European Journal of } \\
\text { Developmental } \\
\text { Psychology }\end{array}$ \\
\hline $\begin{array}{l}\text { Caldas \& } \\
\text { Reilly } 2019 \\
\text { USA }\end{array}$ & 526 & 8 & $\begin{array}{l}\text { Evaluation of } \\
\text { PA } \\
\text { association } \\
\text { with reading, } \\
\text { maths, and } \\
\text { English skills }\end{array}$ & 1 day & $\begin{array}{l}\text { Mutual influence } \\
\text { among physical } \\
\text { skills, } \\
\text { mathematical } \\
\text { ones, reading, and } \\
\text { English. }\end{array}$ & $\begin{array}{l}\text { Journal of Research } \\
\text { in Childhood } \\
\text { Education }\end{array}$ \\
\hline $\begin{array}{l}\text { De Bruijn et } \\
\text { al. } 2019 \\
\text { Netherlands }\end{array}$ & 891 & 9 & $\begin{array}{l}\text { Motor activity, } \\
\text { maths, reading } \\
\text { and spelling }\end{array}$ & 2 weeks & $\begin{array}{l}\text { Motor skills } \\
\text { influence } \\
\text { academic results } \\
\text { and, with aerobic } \\
\text { fitness, are } \\
\text { predictive of } \\
\text { maths outcomes }\end{array}$ & $\begin{array}{l}\text { Psychology of } \\
\text { Sport \& Exercise }\end{array}$ \\
\hline $\begin{array}{l}\text { Duijzer et al. } \\
2019 \\
\text { Netherlands }\end{array}$ & 70 & $9-11$ & $\begin{array}{l}\text { Reflecting, } \\
\text { while moving } \\
\text { through } \\
\text { spaces, on } \\
\text { distance - } \\
\text { movement } \\
\text { charts. }\end{array}$ & $\begin{array}{l}6 \text { weeks, 50- } \\
\text { minute } \\
\text { weekly } \\
\text { lessons }\end{array}$ & $\begin{array}{l}\text { The tangible } \\
\text { management of } \\
\text { variables (VS } \\
\text { only iconic } \\
\text { learning) } \\
\text { contributes to } \\
\text { develop complex } \\
\text { maths thinking. }\end{array}$ & $\begin{array}{l}\text { ZDM: Mathematics } \\
\text { Education }\end{array}$ \\
\hline $\begin{array}{l}\text { Egger et al. } \\
2019 \\
\text { Switzerland }\end{array}$ & 142 & $7-9$ & $\begin{array}{l}\text { Breaks with } \\
\text { activities } \\
\text { involving the } \\
\text { physical and } \\
\text { cognitive } \\
\text { dimensions }\end{array}$ & 20 weeks & $\begin{array}{l}\text { PA and adequate } \\
\text { cognitive } \\
\text { stimulation are } \\
\text { beneficial for } \\
\text { executive } \\
\text { functions and } \\
\text { maths }\end{array}$ & PLOS ONE \\
\hline $\begin{array}{l}\text { Seljebotn et } \\
\text { al. } 2019 \\
\text { Norway }\end{array}$ & 447 & $9-10$ & $\begin{array}{l}\text { Lessons with } \\
\text { integrated PA, } \\
\text { active school } \\
\text { breaks, and } \\
\text { "active" } \\
\text { homework. }\end{array}$ & 10 months & $\begin{array}{l}\text { Improved } \\
\text { children activity } \\
\text { levels. No } \\
\text { negative effects } \\
\text { on academic } \\
\text { outcomes }\end{array}$ & $\begin{array}{l}\text { Preventive } \\
\text { Medicine Reports }\end{array}$ \\
\hline
\end{tabular}




\begin{tabular}{|c|c|c|c|c|c|c|}
\hline $\begin{array}{l}\text { Van Den Berg } \\
\text { et al. } 2019 \\
\text { Netherlands }\end{array}$ & 312 & $10-11$ & $\begin{array}{l}\text { Integration of } \\
\text { dexterity } \\
\text { games with } \\
\text { maths } \\
\text { teaching. }\end{array}$ & $\begin{array}{l}5 \text { weeks, } 20 \\
\text { lessons ( } 5 \text { to } \\
8 \text { minutes } \\
\text { each) }\end{array}$ & $\begin{array}{l}\text { Increased lesson } \\
\text { appreciation; } \\
\text { irrelevant } \\
\text { academic results }\end{array}$ & $\begin{array}{l}\text { International } \\
\text { Journal of } \\
\text { Environmental } \\
\text { Research and } \\
\text { Public Health }\end{array}$ \\
\hline $\begin{array}{l}\text { Vetter et al. } \\
2019 \text { Australia }\end{array}$ & 172 & 8 & $\begin{array}{l}\text { Maths } \\
\text { lessons with } \\
\text { or without PA }\end{array}$ & 6 weeks & $\begin{array}{l}\text { Times tables } \\
\text { improvements and } \\
\text { more active } \\
\text { lifestyle }\end{array}$ & $\begin{array}{l}\text { Journal of Science } \\
\text { and Medicine in } \\
\text { Sport }\end{array}$ \\
\hline $\begin{array}{l}\text { Watson et al. } \\
2019 \text { Australia }\end{array}$ & 374 & $8-9$ & $\begin{array}{l}\text { ACTI-BREAK } \\
\text { program; } \\
\text { effects on } \\
\text { learning and } \\
\text { behaviour }\end{array}$ & $\begin{array}{l}6 \text { weeks, } 5 \\
\text { active breaks } \\
\text { ( } 3 \text { mins each) } \\
\text { daily }\end{array}$ & $\begin{array}{l}\text { Improved } \\
\text { concentration } \\
\text { during lessons; no } \\
\text { significant direct } \\
\text { effects on reading } \\
\text { and maths }\end{array}$ & $\begin{array}{l}\text { Journal of Science } \\
\text { and Medicine in } \\
\text { Sport }\end{array}$ \\
\hline $\begin{array}{l}\text { Mavilidi et al. } \\
2020 \text { Australia }\end{array}$ & 87 & $9-10$ & $\begin{array}{l}\text { Effects of } \\
\text { active breaks } \\
\text { (at school) on } \\
\text { learning. }\end{array}$ & $\begin{array}{l}4 \text { weeks; } 3 \\
\text { times per } \\
\text { week, } 5- \\
\text { minute } \\
\text { activities }\end{array}$ & $\begin{array}{l}\text { Improved } \\
\text { concentration. No } \\
\text { negative impact of } \\
\text { increased PA time } \\
\text { on learning maths } \\
\text { and other } \\
\text { subjects. }\end{array}$ & Acta Paediatrica \\
\hline
\end{tabular}

(Source: own processing). (Legend: $P A=$ physical activity, Subj = subjects, mins $=$ minutes).

\section{RESULTS}

Research shows the role that physical activity has in promoting cognitive development; if this concerns all disciplines, among them there seems to be a rather strong correlation between logical-mathematical skills and physical activity.

\section{Compliance of the experimental protocols with ethical standards}

All the analysed protocols were carried out in full compliance with the ethics laws and regulations of the various countries and after all the parties involved, both institutional and private (children and families) had been informed and had given their consent to the participation of the minors in the activities.

\section{Research localization}

From the analysis of the studies, an immediately recognisable characteristic is their worldwide diffusion; in Anglo-Saxon countries (the USA and Australia), there is the highest number of research. However, a considerable number of protocols is present in Northern Europe (the Netherlands, Norway, Sweden, Denmark) whereas, at least in our research, there is no equal presence in the remaining European countries.

\section{Research duration}

As far as the duration of the various studies is concerned, they range from three years (Donnelly et al., 2009) to a few days (Vazou \& Smiley-Oyen, 2014). Most of the research lasted between three (Elofsson et al., 2018) and twenty-one weeks (Mullender-Wijnsma et al., 2015).

\section{Primary research objective}

The primary research objective was to investigate the correlation between physical activity and mathematics and how this could influence the process of learning these disciplines. In none of the studies, have there 
been negative results on learning: neither in mathematics nor in physical education or other subjects different from the ones that were primarily involved in the research.

In almost all studies there have been positive effects on learning. In two cases (Snyder et al., 2017; Van den Berg et al., 2019) physical activity did not produce substantial direct improvements for mathematics learning but contributed to improving the pupils' ability to stay focused on the tasks to be performed (Snyder et al., 2017) or increased the appreciation of the lesson (Van den Berg et al., 2019) and this can have a generally positive effect on learning and teaching activities.

\section{Long-term effects}

In two protocols (Donnelly et al., 2009; Mullender-Wijnsma et al., 2016) in which the evolution from the initial pre-experimental situation to a time frame wider than a school year was analysed, it was found that there was also an improvement in pupils' attitude towards mathematics and the positive effects of the protocols applied were lasting even beyond the end of the research.

\section{Different impact on the involved subjects}

In most studies the positive results are generalized as they affect all the subjects involved; however, in the research of Resaland et al. (2018), there are gender differences. Those who among male students had been in greater difficulty in the preliminary pupils' disciplinary skills survey carried out by the researchers, obtained the best benefits. This can be compared to the (less good) results obtained by the female students who instead were among the best at mathematics. The researchers interpreted this result as the beneficial effect of a different way of teaching for those pupils who had encountered more difficulties with the established teaching methods. This also led to the consideration of the importance of promoting an increasingly inclusive school. Even in the study of Mullender-Wijnsma et al. (2015) which, beyond mathematics, considered reading skills and the correlation of those two areas of learning with physical activity, there were better results for children who attended the third year of primary school, compared to those in the second year. According to the researchers, further analyses could be carried out to understand the specificity of the activities to be implemented in relation to children's age.

\section{Further noticed effects}

The implementation of the various experimental protocols led to an increase in physical activity and a decrease in sedentary lifestyle (e.g., time spent sitting) during the school day; this change did not have any negative impact on children's academic performance. During the activities, the researchers reported a perceived positive environment also from an emotional point of view and, besides, active participation and involvement by both pupils and teachers and the whole school context.

\section{DISCUSSION}

From the analysis of the studies and their correlation with the purposes of our research, it was possible to observe some common characteristics and then trace cross-cutting issues due to which these studies could be considered as an own wider category of didactics approach.

\section{Characteristics of the studies}

Considering the structure of the experiments, we can divide the studies into two categories. One comprises protocols in which a disciplinary integration between physical activity and mathematics is carried out through lessons that have a higher or lower frequency during the school week (Duijzer et al., 2019; Vazou \& Skrade, 2017; Mullender - Wijnsma et al., 2015; Elofsson et al., 2018; Riley et al., 2015; Have et al., 2018). 
The other group of studies instead is characterized by the insertion of physical activity in the breaks among lessons. The breaks might be either already existing or introduced specifically for this purpose; the duration of the breaks is comprised between 3 and 10 minutes (Watson et al., 2019; Mavilidi et al., 2020; Goh et al., 2016).

\section{Research contexts}

About the contexts where the protocols have been implemented, a common trait that can be found is the consistent adaptability of the research. That is since all studies can be carried out in the various settings within the school context; be it either in the gym or outdoors (after due adjustments) or in the classroom. In a study (Seljebotn et al., 2019) the protocol also includes some extracurricular time with the assignment of tasks, such as homework, that involve physical activity.

\section{Assets management}

In almost all studies the use of the available equipment at school allows for carrying out all activities. Particular tools or resources are generally not necessary. Only in the study conducted by Agostinho et al. (2015) iPads are required. In the protocol developed by Smith et al. (2014) instead, researchers have created an application to let pupils learn problems on the topic of angles through the usage of Windows Kinect $($. In almost all the studies there is therefore a parsimonious approach to the resources of the educational institutions that have been involved in the various trial implementations.

\section{Equipment used}

In the various studies, tools such as accelerometers and/or pedometers have been used by researchers to obtain objective and scientifically evaluable measures on the types of the movement carried out during the trials, both in quantitative and qualitative terms.

\section{Possibilities of widening the interdisciplinarity}

In some studies, it has been observed how physical activity could be correlated, resulting in positive outcomes, with other disciplines besides mathematics. There was positive feedback on spelling and reading skills (Mullender-Wijnsma et al., 2016), or improvements in Norwegian, to be understood as the native language, since the study was conducted in Norway by Resaland et al. (2018) and in English (foreign language). In the research of Elofsson et al. (2018) instead, the learning of mathematics is promoted, with positive results, through physical activity and music.

\section{CONCLUSIONS}

After analysing the protocols, it seems to emerge as a shared trait among them the possibility of implementing the proposed activities in other learning environments besides those in which they were tested. The research outcomes on learning of the involved subjects can be considered as positive. Promising effects can be found also for the motivation to study, the active participation of pupils in the activities, and (though not less important) for the emotional dynamics related to the learning process.

Taking those things into consideration seems to suggest that there might be an actual opportunity to improve the learning environments quality through innovative didactics that does, however, not obliterate the tradition. It can also be noted that a more effective modality of approaching the way of teaching the various subjects could be implemented. The educational potential which resides in all of them could be emphasized within the collaborative and interdisciplinary dynamics promoted through that research. 
A further effect stemming from the studies is that related to the increase in physical activity and the corresponding reduction of sedentary time spent by pupils during the school day. This could lead to the structuring of good habits for health and the general well-being of the students that could positively impact on their growth and adult life.

A characteristic that also seems to be important to consider is that related to the effectiveness of the interdisciplinary approach and how it could include disciplines other than physical activity and mathematics. Moreover, integrating further subjects seems to lead to positive effects and this could create a virtuous circle that would foster a holistic approach to the pupil, instead of didactic paths characterized by fragmentation.

The studies we have considered constitute a research sample, even if a relevantly wide and geographically diverse one; however, through further studies it could be evaluated the implementation of similar teaching strategies (suitable for the peculiar and unique condition of every learning context). Thus, a subsequent trial could also be undertaken and, after careful consideration of it, an initial implementation could be carried out.

It would be interesting to experiment with the protocols based on the aforementioned modalities of interdisciplinary integration and evaluate the outcomes through longitudinal studies that would span the entire primary school duration. Therefore, analysing the collected data, it could be possible to understand the impact of this type of didactics in primary school as a whole (not just in a segment of it). Moreover, it could be evaluated how this teaching approach might affect pupils' preparation towards the next step of their educational path (i.e., middle school) and allow the construction of significant competencies for their lives as persons and citizens, beyond the (however important) academic results.

\section{REFERENCES}

Agostinho, S., Tindall-Ford, S., Ginns, P., Howard, S. J., Leahy, W., \& Paas, F. (2015). Giving Learning a Helping Hand: Finger Tracing of Temperature Graphs on an iPad. Educ Psychol Rev, 27(3), 427443. https://doi.org/10.1007/s10648-015-9315-5

Asakawa, A., Murakami, T., \& Sugimura, S. (2019). Effect of fine motor skills training on arithmetical ability in children. Eur J Dev Psychol, 16(3), 290-301. https://doi.org/10.1080/17405629.2017.1385454

Baddeley, A. (2012). Working Memory: Theories, Models, and Controversies. Annu Rev Psychol, 63(1), 1-29. https://doi.org/10.1146/annurev-psych-120710-100422

Barsalou, L. (2008). Grounded Cognition. Annu Rev Psychol, 59, 617-645. https://doi.org/10.1146/annurev.psych.59.103006.093639

Barsalou, L. W. (2010). Grounded Cognition: Past, Present, and Future. Top Cogn Sci, 2(4), 716-724. https://doi.org/10.1111/j.1756-8765.2010.01115.x

Barsalou L. W. (1999). Perceptual symbol systems. Behav. Brain Sci. 22:577-660 https://doi.org/10.1017/S0140525X99002149

Blair, C., \& Razza, R. P. (2007). Relating Effortful Control, Executive Function, and False Belief Understanding to Emerging Math and Literacy Ability in Kindergarten. Child Dev, 78(2), 647-663. https://doi.org/10.1111/j.1467-8624.2007.01019.x

Caldas, S. J., \& Reilly, M. S. (2019). The Mediating Influence of Physical Activity Levels on 3rd-Grade Academic Achievement. J Res Childhood Educ, 33(2), 271-289. https://doi.org/10.1080/02568543.2019.15777775 
Chaddock, L., Erickson, K. I., Prakash, R. S., VanPatter, M., Voss, M. W., Pontifex, M. B., Raine, L. B., Hillman, C. H., \& Kramer, A. F. (2010). Basal Ganglia Volume Is Associated with Aerobic Fitness in Preadolescent Children. Dev Neurosci-Basel, 32(3), 249-256. https://doi.org/10.1159/000316648

Cotman, C. W., Berchtold, N. C., \& Christie, L.-A. (2007). Exercise builds brain health: Key roles of growth factor cascades and inflammation. Trends Neurosci, 30(9), 464-472. https://doi.org/10.1016/j.tins.2007.06.011

Davis, C. L., Tomporowski, P. D., McDowell, J. E., Austin, B. P., Miller, P. H., Yanasak, N. E., Allison, J. D., \& Naglieri, J. A. (2011). Exercise Improves Executive Function and Achievement and Alters Brain Activation in Overweight Children: A Randomized Controlled Trial. Health Psychol, 30(1), 91-98. https://doi.org/10.1037/a0021766

De Bruijn, A. G. M., Kostons, D. D. N. M., van der Fels, I. M. J., Visscher, C., Oosterlaan, J., Hartman, E., \& Bosker, R. J. (2019). Importance of aerobic fitness and fundamental motor skills for academic achievement. Psychol Sport Exerc, 43, 200-209. https://doi.org/10.1016/j.psychsport.2019.02.011

De Greeff, J. W., Bosker, R. J., Oosterlaan, J., Visscher, C., \& Hartman, E. (2018). Effects of physical activity on executive functions, attention and academic performance in preadolescent children: $A$ meta-analysis. J Sci Med Sport, 21(5), 501-507. https://doi.org/10.1016/i.jsams.2017.09.595

Diamond, A. (2013). Executive Functions. Annu Rev Psychol, 64(1), 135-168. https://doi.org/10.1146/annurev-psych-113011-143750

Donnelly, J. E., Greene, J. L., Gibson, C. A., Smith, B. K., Washburn, R. A., Sullivan, D. K., DuBose, K., Mayo, M. S., Schmelzle, K. H., Ryan, J. J., Jacobsen, D. J., \& Williams, S. L. (2009). Physical Activity Across the Curriculum (PAAC): A randomized controlled trial to promote physical activity and diminish overweight and obesity in elementary school children. Prev Med, 49(4), 336-341. https://doi.org/10.1016/j.ypmed.2009.07.022

Duijzer, C., Van den Heuvel-Panhuizen, M., Veldhuis, M., \& Doorman, M. (2019). Supporting primary school students' reasoning about motion graphs through physical experiences. ZDM, 51(6), 899-913. https://doi.org/10.1007/s11858-019-01072-6

Egger, F., Benzing, V., Conzelmann, A., \& Schmidt, M. (2019). Boost your brain, while having a break! The effects of long-term cognitively engaging physical activity breaks on children's executive functions and academic achievement. PLOS ONE, 14(3), e0212482. https://doi.org/10.1371/journal.pone.0212482

Elofsson, J., Bohm, A. E., Jeppsson, C., \& Samuelsson, J. (2018). Physical activity and music to support pre-school children's mathematics learning. Educ 3-13, 46(5), 483-493. https://doi.org/10.1080/03004279.2016.1273250

Erwin, H., Fedewa, A., \& Ahn, S. (2012). Student Academic Performance Outcomes of a Classroom Physical Activity Intervention: A Pilot Study. IEJEE, 4(3), 473-487. https://files.eric.ed.gov/fulltext/EJ1068595.pdf

Espy, K. A., McDiarmid, M. M., Cwik, M. F., Stalets, M. M., Hamby, A., \& Senn, T. E. (2004). The Contribution of Executive Functions to Emergent Mathematical Skills in Preschool Children. Dev Neuropsychol, 26(1), 465-486. https://doi.org/10.1207/s15326942dn2601_6

Fedewa, A. L., Ahn, S., Erwin, H., \& Davis, M. C. (2015). A randomized controlled design investigating the effects of classroom-based physical activity on children's fluid intelligence and achievement: School Psychol Int, 36(2), 135-153. https://doi.org/10.1177/0143034314565424

Foglia, L., \& Wilson, R. A. (2013). Embodied cognition. Wires Cogn Sci, 4(3), 319-325. https://doi.org/10.1002/wcs.1226

Gashaj, V., Oberer, N., Mast, F. W., \& Roebers, C. M. (2018). The Relation Between Executive Functions, Fine Motor Skills, and Basic Numerical Skills and Their Relevance for Later Mathematics Achievement. Early Educ Dev, 30(7), 913-926. https://doi.org/10.1080/10409289.2018.1539556 
Gathercole, S. E., Pickering, S. J., Knight, C., \& Stegmann, Z. (2004). Working memory skills and educational attainment: Evidence from national curriculum assessments at 7 and 14 years of age. Appl Cognitive Psych, 18(1), 1-16. https://doi.org/10.1002/acp.934

Geary, D. C. (2008). An Evolutionarily Informed Education Science. Educ Psychol, 43(4), 179-195. https://doi.org/10.1080/00461520802392133

Geary, D. C. (1995). Reflections of evolution and culture in children's cognition: Implications for mathematical development and instruction. Am Psychol, 50(1), 24-37. https://doi.org/10.1037/0003066X.50.1.24

Goh, T. L., Hannon, J., Webster, C., Podlog, L., \& Newton, M. (2016). Effects of a TAKE 10! Classroombased physical activity intervention on third-to fifth-grade children's on-task behavior. J Phys Act Health, 13(7), 712-718. https://doi.org/10.1123/ipah.2015-0238

Griffo, J. M., Kulinna, P., Hicks, L., \& Pangrazi, C. (2018). Becoming One in the Fitness Segment: Physical Education and Mathematics. Phys Educator, 75(4), 647-660. https://doi.org/10.18666/TPE2018-V75-14-8199

Have, M., Nielsen, J. H., Ernst, M. T., Gejl, A. K., Fredens, K., Grøntved, A., \& Kristensen, P. L. (2018). Classroom-based physical activity improves children's math achievement - A randomized controlled trial. PLOS ONE, 13(12), e0208787. https://doi.org/10.1371/journal.pone.0208787

Howie, E. K., Schatz, J., \& Pate, R. R. (2015). Acute Effects of Classroom Exercise Breaks on Executive Function and Math Performance: A Dose-Response Study. Res Q Exercise Sport, 86(3), 217-224. https://doi.org/10.1080/02701367.2015.1039892

Hu, F.-T., Ginns, P., \& Bobis, J. (2015). Getting the point: Tracing worked examples enhances learning. Learn Instr, 35, 85-93. https://doi.org/10.1016//.learninstruc.2014.10.002

Lopes, L., Santos, R., Pereira, B., \& Lopes, V. P. (2013). Associations between gross Motor Coordination and Academic Achievement in elementary school children. Hum Movement Sci, 32(1), 9-20. https://doi.org/10.1016/i.humov.2012.05.005

Mavilidi, M. F., Drew, R., Morgan, P. J., Lubans, D. R., Schmidt, M., \& Riley, N. (2020). Effects of different types of classroom physical activity breaks on children's on-task behaviour, academic achievement and cognition. Acta Paediatr, 109(1), 158-165. https://doi.org/10.1111/apa.14892

Mavilidi, M.-F., Okely, A., Chandler, P., Louise Domazet, S., \& Paas, F. (2018). Immediate and delayed effects of integrating physical activity into preschool children's learning of numeracy skills. J Exp Child Psychol, 166, 502-519. https://doi.org/10.1016/i.jecp.2017.09.009

Meister, I. G., Boroojerdi, B., Foltys, H., Sparing, R., Huber, W., \& Töpper, R. (2003). Motor cortex hand area and speech: Implications for the development of language. Neuropsychologia, 41(4), 401-406. https://doi.org/10.1016/S0028-3932(02)00179-3

Meyer, D. K., \& Turner, J. C. (2007). Scaffolding Emotions in Classrooms. In Emotion in Education (p. 243-258). Elsevier. https://doi.org/10.1016/B978-012372545-5/50015-0

Miyake, A., Friedman, N. P., Emerson, M. J., Witzki, A. H., Howerter, A., \& Wager, T. D. (2000). The Unity and Diversity of Executive Functions and Their Contributions to Complex "Frontal Lobe" Tasks: A Latent Variable Analysis. Cognitive Psychol, 41(1), 49-100. https://doi.org/10.1006/cogp.1999.0734

Moher, D., Liberati, A., Tetzlaff, J., \& Altman, D. G. (2009). Preferred reporting items for systematic reviews and meta-analyses: The PRISMA statement. Ann intern med, 151(4), 264-269. https://doi.org/10.1371/journal.pmed.1000097

Moreno, R. (2010). Cognitive load theory: More food for thought. Instr Sci, 38(2), 135-141. https://doi.org/10.1007/s11251-009-9122-9

Morrison, F. J., Ponitz, C. C., \& McClelland, M. M. (2010). Self-regulation and academic achievement in the transition to school. In S. D. Calkins \& M. A. Bell (A c. Di), Child development at the intersection 
of emotion and cognition. (p. 203-224). American Psychological Association. https://doi.org/10.1037/12059-011

Mullender-Wijnsma, M. J., Hartman, E., de Greeff, J. W., Doolaard, S., Bosker, R. J., \& Visscher, C. (2016). Physically Active Math and Language Lessons Improve Academic Achievement: A Cluster Randomized Controlled Trial. Pediatrics, 137(3), e20152743. https://doi.org/10.1542/peds.2015$\underline{2743}$

Mullender-Wijnsma, M. J., Hartman, E., Greeff, J. W. de, Bosker, R. J., Doolaard, S., \& Visscher, C. (2015). Improving Academic Performance of School-Age Children by Physical Activity in the Classroom: 1-Year Program Evaluation. J School Health, 85(6), 365-371. https://doi.org/10.1111/josh.12259

Raver, C. C., \& Blair, C. (2016). Neuroscientific Insights: Attention, Working Memory, and Inhibitory Control. Future Child, 26(2), 95-118. JSTOR. https://www.jstor.org/stable/43940583

Resaland, G. K., Moe, V. F., Bartholomew, J. B., Andersen, L. B., McKay, H. A., Anderssen, S. A., \& Aadland, E. (2018). Gender-specific effects of physical activity on children's academic performance: The Active Smarter Kids cluster randomized controlled trial. Prev Med, 106, 171-176. https://doi.org/10.1016/i.ypmed.2017.10.034

Riley, N., Lubans, D. R., Morgan, P. J., \& Young, M. (2015). Outcomes and process evaluation of a programme integrating physical activity into the primary school mathematics curriculum: The EASY Minds pilot randomised controlled trial. J Sci Med Sport, 18(6), 656-661. https://doi.org/10.1016/i.jsams.2014.09.005

Rizzolatti, G., \& Craighero, L. (2004). The mirror-neuron system. Annu Rev Neurosci, 27(1), 169-192. https://doi.org/10.1146/annurev.neuro.27.070203.144230

Ruiter, M., Loyens, S., \& Paas, F. (2015). Watch Your Step Children! Learning Two-Digit Numbers Through Mirror-Based Observation of Self-Initiated Body Movements. Educ Psychol Rev, 27(3), 457474. https://doi.org/10.1007/s10648-015-9324-4

Seljebotn, P. H., Skage, I., Riskedal, A., Olsen, M., Kvalø, S. E., \& Dyrstad, S. M. (2019). Physically active academic lessons and effect on physical activity and aerobic fitness. The Active School study: A cluster randomized controlled trial. Prev Med Rep, 13, 183-188. https://doi.org/10.1016/i.pmedr.2018.12.009

Smith, C. P., King, B., \& Hoyte, J. (2014). Learning angles through movement: Critical actions for developing understanding in an embodied activity. J Math Behavior, 36, 95-108. https://doi.org/10.1016/i.jmathb.2014.09.001

Snyder, K., Dinkel, D., Schaffer, C., Hiveley, S., \& Colpitts, A. (2017). Purposeful Movement: The Integration of Physical Activity into a Mathematics Unit. Int J Res Educ Sci, 3(1), 75-87. https://eric.ed.gov/?id=EJ1126688

Sweller, J. (1988). Cognitive Load During Problem Solving: Effects on Learning. Cognitive Sci, 12(2), 257-285. https://doi.org/10.1207/s15516709cog1202_4

Sweller, J. (2006). The worked example effect and human cognition. Learn Instr, 16(2), 165-169. https://doi.org/10.1016/i.learninstruc.2006.02.005

Van den Berg, V., Singh, A. S., Komen, A., Hazelebach, C., van Hilvoorde, I., \& Chinapaw, M. J. M. (2019). Integrating Juggling with Math Lessons: A Randomized Controlled Trial Assessing Effects of Physically Active Learning on Maths Performance and Enjoyment in Primary School Children. Int J Env Res Pub He, 16(14), 2452. https://doi.org/10.3390/ijerph16142452

Vazou, S., \& Skrade, M. A. B. (2017). Intervention integrating physical activity with math: Math performance, perceived competence, and need satisfaction. Int J Sport Exercise Psychol, 15(5), 508522. https://doi.org/10.1080/1612197X.2016.1164226 
Vazou, S., \& Smiley-Oyen, A. (2014). Moving and Academic Learning Are Not Antagonists: Acute Effects on Executive Function and Enjoyment. J Sport Exercise Psy, 36(5), 474-485. https://doi.org/10.1123/isep.2014-0035

Vetter, M., O'Connor, H. T., O'Dwyer, N., Chau, J., \& Orr, R. (2019). 'Maths on the move': Effectiveness of physically-active lessons for learning maths and increasing physical activity in primary school students. J Sci Med Sport. https://doi.org/10.1016/i.jsams.2019.12.019

Vetter, M., O'Connor, H., O'Dwyer, N., \& Orr, R. (2018). Learning «Math on the Move»: Effectiveness of a Combined Numeracy and Physical Activity Program for Primary School Children. J Phys Act Health, 15(7), 492-498. https://doi.org/10.1123/ipah.201734

Watson, A. J. L., Timperio, A., Brown, H., \& Hesketh, K. D. (2019). A pilot primary school active break program (ACTI-BREAK): Effects on academic and physical activity outcomes for students in Years 3 and 4. J Sci Med Sport, 22(4), 438-443. https://doi.org/10.1016/j.jsams.2018.09.232

\section{(), $\odot \Theta \Theta$}

This work is licensed under a Attribution-NonCommercial-NoDerivatives 4.0 International (CC BY-NC-ND 4.0). 